Int. J. Dev. Biol. 62: 177-182 (2018)

https://doi.org/10.1387/ijdb.170297rk

\title{
Segmentation of the chick central and peripheral nervous systems
}

\author{
ROGER KEYNES* and GEOFFREY COOK \\ Department of Physiology, Development \& Neuroscience. University of Cambridge, Cambridge, UK
}

\begin{abstract}
The chick embryo has provided a prominent model system for the study of segmental patterning in the nervous system. During early development, motor and sensory axon growth cones traverse the anterior/rostral half of each somite, so avoiding the developing vertebral components and ensuring separation of spinal nerves from vertebral bones. A glycoprotein expressed on the surface of posterior half-somite cells confines growth cones to the anterior half-somites by a contact repulsive mechanism. Hindbrain segmentation is also a conspicuous feature of chick brain development. We review how its contemporary analysis was initiated in the chick embryo, and the advantages the chick system continues to provide in its detailed elucidation at both molecular and neural circuit levels.
\end{abstract}

KEY WORDS: somite, rhombomere, hindbrain, contact repulsion, lectin

\section{Introduction}

The chick embryo has been a favoured subject of study by developmental biologists since (at least) the time of Aristotle. Centuries later its value for understanding circulatory physiology was not lost on William Harvey. Since the early $19^{\text {th }}$ century, with the advent of light microscopy, it has played a key role in both descriptive and experimental embryology. In the field of neuroscience Ramon y Cajal discovered the axon growth cone using the chick embryo (García-Marín et al., 2009). Viktor Hamburger (Fig. 1) developed the neurotrophic hypothesis using the chick embryo, famously commenting that 'the embryo is the only teacher who is always right'. And Lynn Landmesser and Cynthia Lance-Jones (1980) demonstrated specificity in the pathfinding of chick motor axons growing from individual motor neuron pools in the spinal cord to their target muscles. With the advent of sophisticated molecular techniques more recently, studying the chick embryo has undergone a resurgence. Here we discuss how it has helped to provide insights into developmental patterning in the nervous system and, simultaneously, the molecular regulation of nerve growth.

A basic patterning mechanism in the early nervous system concerns its subdivision into repeat units, or segments, during the development of both central and peripheral nervous systems (CNS and PNS). At the anatomical/descriptive level of developing neurons and their axons, these processes are conserved between birds and mammals. We argue, therefore, that the study of neural segmentation in the chick is likely to be of direct relevance to understanding human developmental neuroanatomy. In the CNS this concerns the hindbrain (pons and medulla, see below). In the PNS it concerns the repeat pattern of spinal (motor and sensory) peripheral nerves.

\section{PNS segmentation}

Peripheral spinal nerves necessarily enter and exit the spinal cord without mechanical obstruction or interference by the developing vertebral elements that are designed to surround and protect it. One has only to remember the acute pain commonly experienced following intervertebral disc prolapse to appreciate the importance of keeping spinal nerves and vertebral components physically separate. It is now well established that the separation results from an interaction between spinal nerve growth cones and the periodic series of somites that generate the vertebrae. Motor and sensory axons project laterally, respectively, from the ventral spinal cord and the dorsal root ganglia. In doing so they avoid growing through the posterior $(P$, caudal) half of each somite-derived sclerotome, instead traversing exclusively each anterior (A, rostral/cranial) half (Fig. 2).

This polarization of the somites into two halves, one containing the spinal (dorsal root) ganglion (DRG) and the other generating

Abbreviations used in this paper: CNS, central nervous system; PNS, peripheral nervous system.

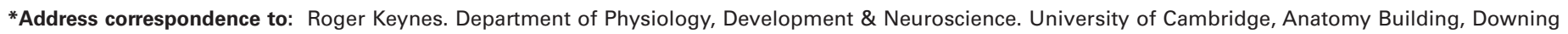

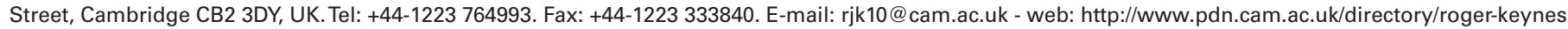




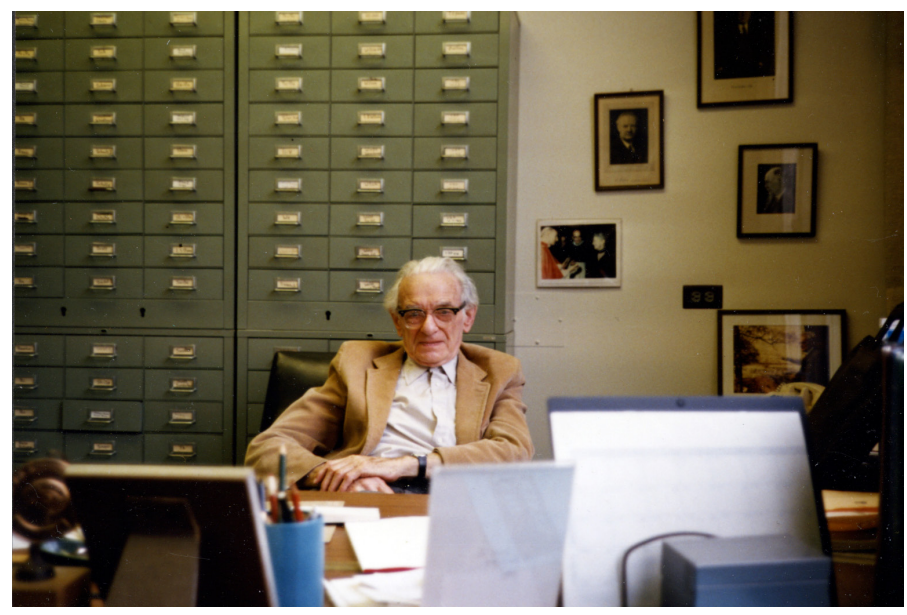

Fig. 1. Viktor Hamburger in 1987. Viktor Hamburger, photographed by Dennis O'Leary in VH's office in the Department of Anatomy and Neurobiology, Washington University, St Louis, USA, when RK had the pleasure of meeting him. The two photographs over his left shoulder are of (top) Hans Spemann, his doctoral advisor, and (bottom) of his colleague Rita Levi-Montalcini meeting Pope Paul VIth

vertebral cartilage and bone, was first pointed out in 1855 by the great pioneer of descriptive chick embryology and cell theory, Robert Remak (Fig. 3). As argued by Harris (2000), Remak's prior observations in 1841 on dividing chick embryo nucleated red cells were critical for his view that animal cell division takes place by binary fission. Moreover, his proposal that vertebrae form by a recombination or frame-shift of neighbouring halfsclerotomes from adjacent somites is well accepted (Fleming et al., 2015). But his finding regarding the position of spinal ganglia in the 'protovertebrae' (sclerotomes, Fig. 3) was left unanalyzed. Its rediscovery in the 1980s and its further investigation showed that both motor and sensory axons preferentially associate with cells of the anterior half-sclerotome (Keynes and Stern, 1984).

Taking advantage of the ready accessibility of the somite-stage chick embryo for 'cut and paste' microsurgical experiments, we first addressed whether the segmented outgrowth results from some intrinsic property of the neural tube or whether it is imposed instead by properties of the half-somites. This was tested by microsurgical rotation of the neural tube relative to the somite mesoderm, so that neural tube normally opposite the anterior halves of the somites was now placed opposite the posterior halves. In all eleven experiments this displacement resulted in axon outgrowth remaining confined to the anterior half-somites, indicating that the neural tube is not intrinsically segmented with respect to axon outgrowth. To see whether segmentation results instead from a property of the somites, the presomitic mesoderm (PSM) was rotated through $180^{\circ}$, leaving the neural tube undisturbed. When strips of PSM several prospective somites in length underwent A-P rotation followed by host implantation, in all cases axonal growth was confined to the posterior (original anterior) halves of the grafted somites (Keynes and Stern, 1984).

These experiments showed that somite patterning imposes the segmented outgrowth pattern on spinal nerves, and revealed an intriguing resemblance between vertebrate somites and the A-P sub-division of insect epidermal segments (Lewis, 1984). They also raised important questions concerning the molecular properties responsible for mediating this binary choice of outgrowing axons. Stern et al., (1986) set about addressing this by assessing lectin staining of chick somites, which revealed the first evidence of a molecular difference between the A- and P-half-sclerotome. Lectins, as a class of plant proteins with the ability to agglutinate cells and exhibit sugar-specific binding, were known in the 19th century but only became more widely available to biologists in the 1960s. An interest in lectins as biochemical tools was greatly stimulated by then-contemporary studies showing the need to consider sugars as important molecular species at the cell surface. In the two decades following the 1960s the literature on the lectins increased nearly twenty-fold (Liener et al., 1986), and well over a hundred had been purified and were available commercially. Stern et al., (1986) made good use of the availability of purified lectins to study their binding to cryostat sections of chick embryos. Using a panel of four horseradish-peroxidase-conjugated lectins they showed that one of these, peanut agglutinin (PNA), is able to discriminate in a carbohydrate-specific manner between $A$ - and $\mathrm{P}$-half-sclerotome both in vitro and in the embryo. They found that PNAbinds preferentially to P-half-sclerotome, and suggested that the disaccharide D-galactose-N-acetyl-D-galactosamine may be associated with an important molecule.

Following these studies Davies et al., (1990) extended the histochemistry to include the use of another lectin, Jacalin, obtained from jackfruit. This recognises the same Gal $\beta 1-3 \mathrm{GaINAc}$ structure as does PNA, but whereas PNA is unable to bind to the sialylated glycan, Jacalin binds whether the glycan is sialylated or not. Davies et al., (1990) also used the recently devised growth cone collapse assay (Kapfhammer and Raper, 1987) to show that these two lectins, when immobilized on agarose beads, were each capable of removing a collapse-inducing activity of detergentsolubilized chick somite extract. Collapse of DRG growth cones was detected in the presence of nerve growth factor (NGF), and its removal by PNA correlated with removal of two major proteins (of MW 48 \& 55K) that are absent from the A-half-somites. Rabbit polyclonal antibodies raised against these proteins recognized only $\mathrm{P}$-half-sclerotome cells, and when immobilized on agarose beads the antibodies could also be used to eliminate collapse-inducing activity from detergent extracts of chick embryo somites. Davies et al., (1990) therefore suggested that spinal nerve segmentation

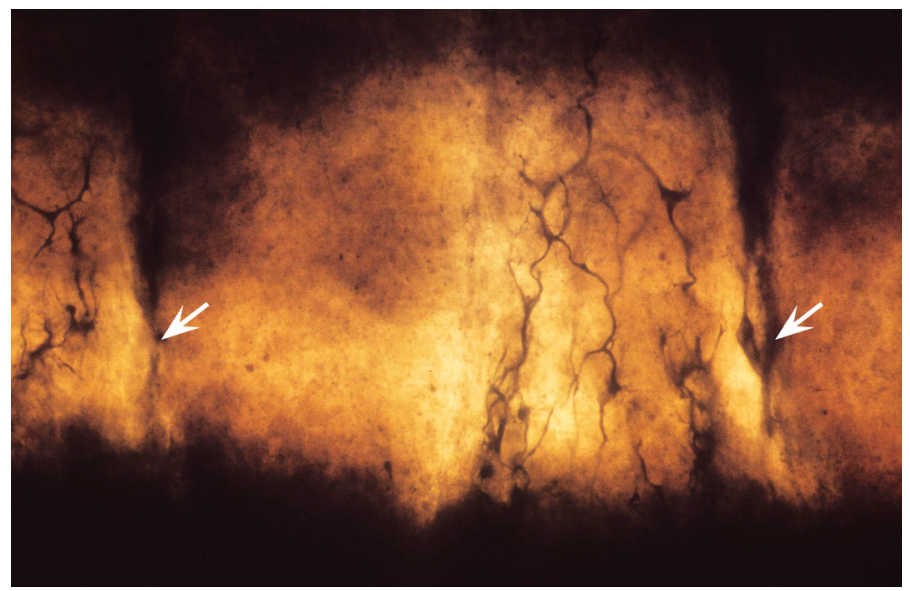

Fig. 2. Spinal nerve outgrowth into the chick somite. Motor axons, stained with zinc iodide and osmium tetroxide, grow from the neural tube (below) into the anterior (right) half of the somite. The somite boundaries are indicated by arrows. 


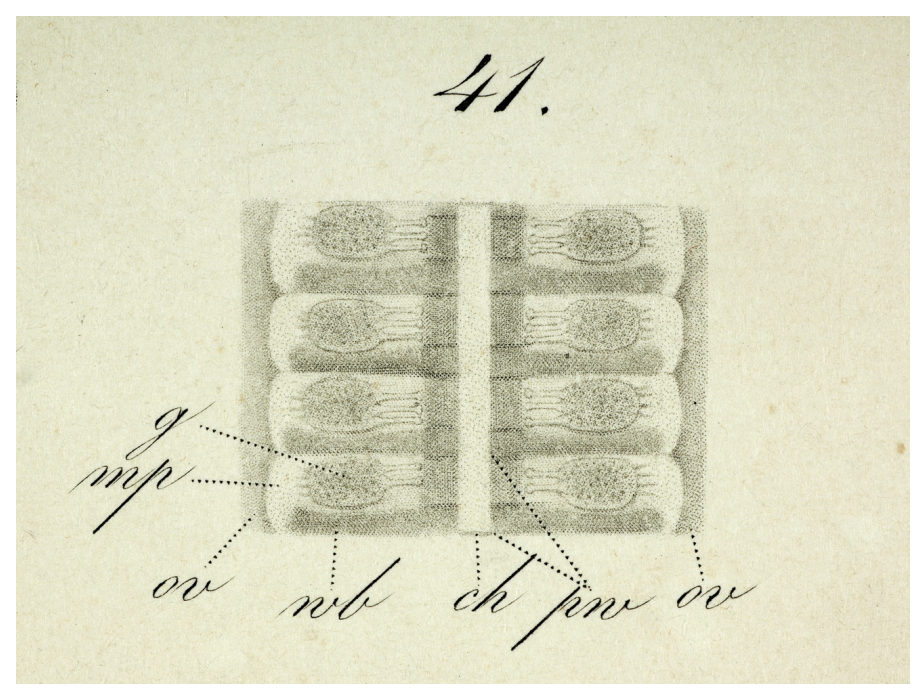

Fig. 3. The polarized somite. Robert Remak's illustration of segments in the chick embryo somite mesoderm, reproduced from Remak's book Untersuchungen über die Entwicklung derWirbelthiere (1855). The dorsal root ganglia (g) lie in the upper (anterior/rostral) parts of four segments (sclerotomes or 'protovertebrae', prv) on each side of the midline notochord (ch).

is produced by inhibitory/repulsive interactions between these molecules and axon growth cones. Recent experiments in our laboratory have used PNA-affinity chromatography to identify a cell surface glycoprotein expressed on the surface of P-half sclerotome cells that mediates this process (G. Cook and R. Keynes, unpublished observations).

Insight into the mechanism of action of these molecules came from two subsequent studies using the chick embryo. Keynes et al., (1997) co-cultured chick embryo tissues embedded in collagen gels to test whether the orientation of axons sprouting from DRGs under the influence of NGF is influenced by diffusible cues from neighbouring tissues. Indeed, axons extending from DRGs sandwiched between explants of somite-derived dermomyotome and notochord extend a bipolar trajectory between them, a phenomenon termed 'surround repulsion'. Similar experiments showed that dissected P-half-sclerotomes exert no such long-distance repulsion on DRG growth cones, suggesting that contact repulsion is the primary mechanism underlying spinal nerve segmentation.

Further support for this suggestion came two years later from a careful study by Steketee and Tosney (1999), who examined how chick growth cones interact in vitro with single P-half-sclerotome cells. Growth cones extend both filopodia (finger-like protrusions) and lamellipodia (veil/sheet-like processes) that are necessary for pathfinding. Filopodial contact with a P-half-sclerotome cell is essential for initiation of the repulsive response. Contact is rapidly followed by filopodial retraction and local lamellipodial retraction, while more distant lamellipodia continue to extend with non-contacting filopodia. Within 2.5 minutes of losing contact, lamellipodial extension is restored to the leading edge of the growth cone and it steers away from the cell.

These various lines of evidence have shown that the A-P somite polarization generates spinal nerve segmentation in both birds and mammals. By sequential contact repulsion in successive somites, a gating mechanism forces an otherwise continuous linear A-P stream of axons exiting the spinal cord into a punctuated series of separate nerve bundles. It is also clear that, as predicted, experimental alteration of the upstream molecular mechanisms that create the polarity disturbs spinal nerve segmentation. For example, the transcription factor Mesp2 generates A-half identity, and in its absence the sclerotomes of Mesp2mutant mice develop with P-only identity. Accordingly, spinal nerve axons do not invade the somite (Saga et al., 1997). Reciprocally, mice mutant for the Notch-processor gene Presenilin-1, which generates P-half identity, develop with A-only identity, and spinal axons now extend in the continuous linear A-P stream noted above (Bai et al., 2011).

The A-P somite polarity has also been shown to underlie the selective migration of trunk neural crest cells through A- rather than P-half sclerotome (Rickmann et al.,1985). The chemorepellent sema3F is expressed by P-half-sclerotome cells and has been shown to operate as a neural crest repellent (Gammill et al., 2006). It is interesting that expression of the PNA-binding axon repellent in the sclerotome is not detectable at the early stages of chick crest migration into A-half-sclerotome, coinciding instead with the subsequent phase of axon outgrowth (C. Casper, G. Cook and R. Keynes, unpublished observations). The passage of crest cells and growth cones through somites is therefore likely to be regulated by distinct molecular signals. Consistent with this, axon segmentation is unaffected in mice that are double-mutant for the class-3 semaphorin receptors neuropilin-1 and neuropilin-2 (Huber et al., 2005). The further finding of Gammill et al., (2006) that final segmentation of the DRGs and sympathetic ganglia is undisturbed by disruption of Npn2/Sema3F signalling indicates that ganglion segmentation in the PNS is also regulated by other mechanisms.

Somite polarity has been fully confirmed at the molecular genetic level (Hughes et al., 2009; Saga, 2012; Fleming et al., 2015), and the molecular interactions that generate it have been carefully elucidated in detail, notably by Saga and colleagues using the mouse system (Saga, 2012; Zhao et al., 2015). On the evolutionary side it will be interesting to assess the degree of molecular conservation between chick and mouse in the establishment of A-P somite polarity, given the identity between systems at the anatomical and cellular levels.

\section{Segmentation in the CNS}

\section{Hindbrain segmentation}

Morphological brain segmentation was first recorded in the $19^{\text {th }}$ Century by the embryologist Karl von Baer (1828). In the subsequent light of evolutionary theory these so-called 'neuromeres' (Orr, 1887) were taken by some authors as evidence that the vertebrates were ancestrally segmented, including their heads. Neuromeres reached their anatomical climax when it was claimed by Charles Hill (1899), using the chick embryo, that the entire vertebrate CNS is segmented (Fig. 4). But HV Neal (1918), in a critical review of the field, was less persuaded and concluded that most neuromeres were fixation artefacts. By 1933, in another authoritative review, George Streeter (1933) was sufficiently moved by Hill's image (Fig. 4) to state that: 'To draw a line across the basal plate, saying what is in front of the line is one thing and what is behind it another, is an act of rank pedagogic violence.' Streeter did agree with Neal, however, that the hindbrain segments - rhombomeres - might be more significant. 
By the 1980s, when neuromeres were all but forgotten, it was clear that rhombomeres are not fixation artefacts, being conspicuous in the unfixed chick embryo hindbrain (Fig. 5). It was also clear that their deeper significance would only be reached by establishing whether the patterns of neuronal development within and outside the hindbrain correlate in any way with the morphological segments (Keynes and Stern, 1988). The use of retrograde Dil labelling of the cranial nerve roots proved definitive, identifying both single and two-segment anatomical repeat patterns of hindbrain neuronal development, and their relation to the segmented branchial arches (Lumsden and Keynes, 1989). This was matched, moreover, by simultaneous studies of mouse hindbrain gene expression, which established the rhombomere boundaries as boundaries of Hox gene expression and revealed the alternating repeat pattern of Krox-20 in odd-numbered rhombomeres 2 and 3 (Murphy et al., 1989; Wilkinson et al., 1989).

The chick embryo then contributed critically in the subsequent elucidation of the rhombomeres. Two early studies took advantage of the accessibility of chick rhombomeres in ovo. A clonal analysis, using injection of lysine-rhodamine-dextran into single parent cells, showed that rhombomere boundaries are boundaries of lineage restriction (Fraser et al.,1990; Fig. 6). And a rhombomere grafting/transplantation study revealed an alternating property expressed by cells in odd- versus even-numbered rhombomeres that restricts their inter-mixing (Guthrie and Lumsden, 1991), and that was later attributable to Eph/ephrin signalling (Cayuso et al., 2015; Mellitzer et al., 1999; Xu et al., 1999).

Further chick studies have since defined a variety of rhombomere characteristics. Prominent examples include elucidation of
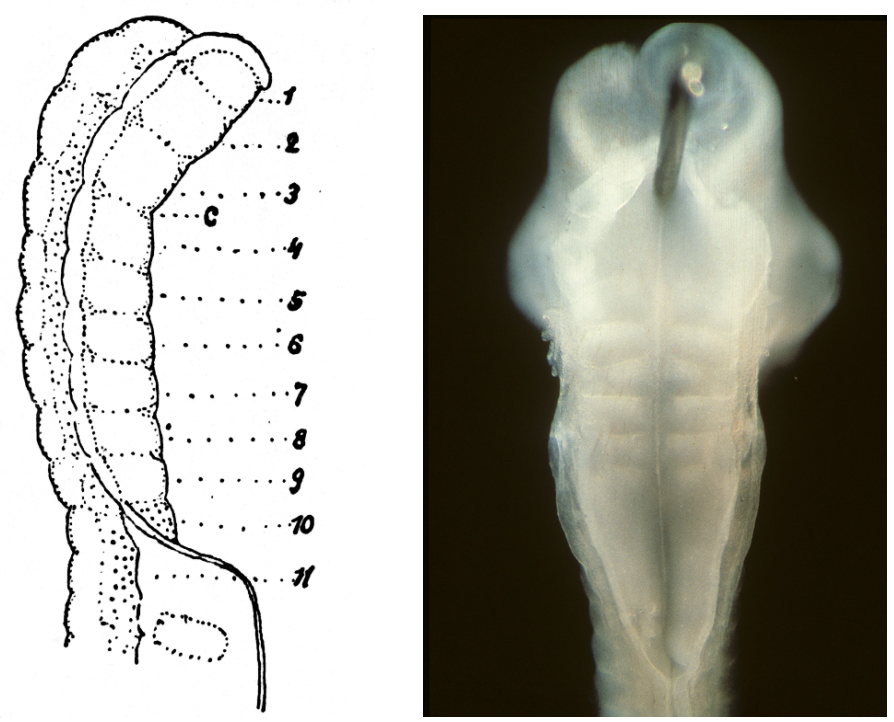

Fig. 4 (left). Chick neuromeres. Charles Hill's drawing (Figure 12 from Hill, Anatomischer Anzeiger, 1899) showing a dorsal view of the anterior portion of the chick neural tube at the 4somite stage. C indicates the anterior limit of the midbrain; segments/neuromeres are numbered. See also Streeter (1933), who commented 'This frequently copied figure illustrates neural segmentation with great daring.

Fig. 5 (right). Chick rhombomeres. Rhombomeres are conspicuous in an unfixed chick embryo photographed at $\mathrm{H} / \mathrm{H}$ stage 20 (Hamburger and Hamilton, 1951). Dorsal view of the hindbrain after removal of the roof plate. the serial repetition of neuronal phenotypes within the rhombomere series (Clarke and Lumsden, 1993), and the rhombomeric origins of the neural crest cells that migrate into the segmented branchial arches and form the basis of craniofacial morphogenesis (Birgbauer et al., 1995; Köntges and Lumsden,1996). Imaging studies of the segmental migration process have also been informative (Kulesa and Fraser, 2000; Kulesa, 2010).

The development of gene electroporation in the chick embryo, and its application in ovo to the highly accessible rhombomere neuroepithelium, has provided a key technical advance (Itasaki et al., 1999; Momose et al., 1999; Muramatsu et al.,1998). An excellent early example of its applicability to rhombomere segmentation was the demonstration that ectopic Krox-20 expression in the cells of even-numbered rhombomeres is sufficient to convert them into odd-numbered $(r 3,5)$ identity (Giudicelli et al., 2001). A more recent example concerns the analysis of Hox4 protein function in regulating cell segregation at the $r 6 / 7$ boundary (Prin et al., 2014).

An important link has also been drawn between hindbrain segmentation and hindbrain function in the analysis of the neuronal circuitry that underlies the respiratory rhythm. This was initiated by recording from branchiomotor nerves using an isolated chick embryo hindbrain preparation (Fortin et al., 1994). The study has been extended in mammalian systems (Chatonnet et al., 2006; Jacquin et al., 1996), and functional anaysis of rhombomerebased respiration circuitry is being undertaken (Sun et al., 2017).

We can anticipate that the segmented chick rhombomeres will continue to illuminate future studies of the development and function of hindbrain circuitry more generally, given the central importance and complexities of brainstem function. In addition to the cranial nerve nuclei and associated circuits, the pons and medulla include other key structures involved in arousal, cardiorespiratory control and motivated behaviours, such as the reticular formation, nucleus tractus solitarius, locus coeruleus and raphe nuclei. A good example showing the utility of the chick system for delineating the axon trajectories and connectivity of specific group of hindbrain ( $\mathrm{dA1}$ ) interneurons is provided by Kohl et al., (2012). Such studies are showing how Hox gene function in the hindbrain is linked to the processes of axon guidance and synaptic targeting in neuronal circuit formation (Di Bonito et al., 2013).

The evolutionary aspects of hindbrain segmentation have also been explored, and Parker et al., (2014) have shown that the system is conserved in the sea lamprey, indicating its presence in the common ancestor of cyclostomes and jawed vertebrates. While its origins in the chordates remain obscure, considerable progress has been made in elucidating the overall Hox gene regulatory network that builds and diversifies hindbrain segmentation (Krumlauf, 2016). The chick embryo continues to prove its utility, for example with the recent demonstration of a pools of neural stem cells at hindbrain boundaries providing differentiating neurons under Sox2 regulation (Peretz et al., 2016). Further developments in chick 3d brain imaging are promising (Gómez-Gaviro et al., 2017), as is the use of Crispr gene editing for manipulating gene function (Oishi et al., 2016; Véron et al., 2015; Wang et al., 2017).

\section{Spinal cord segmentation}

An early lineage study of clonal expansion from single cells labelled in the chick spinal cord showed evidence of an internal 


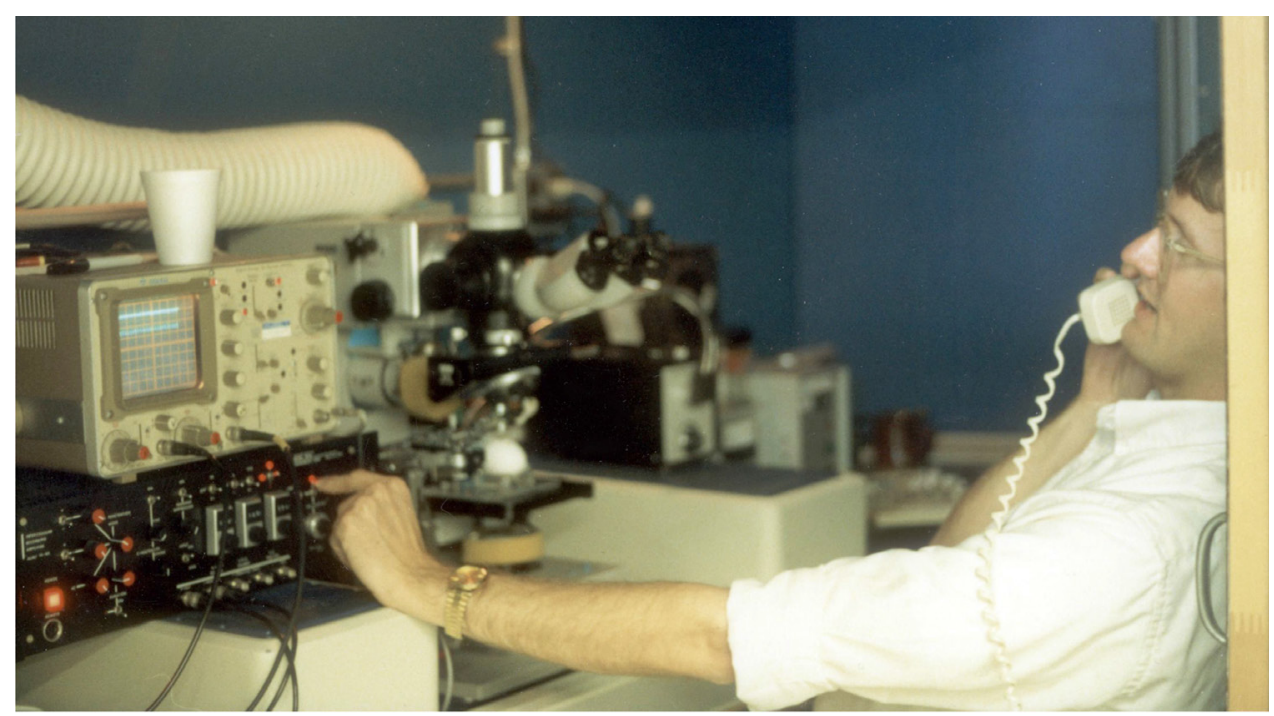

Fig. 6. Scott Fraser at work on an egg in 1989, in his laboratory at the Department of Physiology and Biophysics, University of California, Irvine, USA. The (white) egg can be seen to the right of his left hand, together with the apparatus for single cell labelling in the chick hindbrain. See also Fraser et al., (1990).

\section{References}

BAI G, CHIVATAKARN O, BONANOMI D, LETTIERI K, FRANCO L, XIAC, STEINE, MAL, LEWCOCK JW, PFAFF SL (2011). Presenilin-dependent receptor processing is required for axon guidance. Cell 144: 106-118.

BIRGBAUERE, SECHRIST J, BRONNER-FRASER M, FRASER S (1995). Rhombomeric origin and rostrocaudal reassortment of neural crest cells revealed by intravital microscopy. Development 121: 935-945.

CAYUSO J, XU Q, WILKINSON DG (2015). Mechanisms of boundary formation by Eph receptor and ephrin signaling. Dev Biol 401: 122-131.

CHATONNET F, BORDAY C, WROBEL L, THOBYBRISSON M, FORTIN G, MCLEAN H, CHAMPAGNAT J (2006). Ontogeny of central rhythm generation in chicks and rodents. Respir Physiol Neurobiol 154: 37-46.

CLARKE JD, LUMSDEN A (1993). Segmental repetition of neuronal phenotype sets in the chick embryo hindbrain. Development 118: 151-162.

DAVIES JA, COOK GM, STERN CD, KEYNES RJ (1990). Isolation from chick somites of a glycoprotein fraction that causes collapse of dorsal root ganglion growth cones. Neuron 4: 11-20.

segmental periodicity that is dependent on the adjacent somites for its maintenance (Stern et al., 1991). While its significance is uncertain, it is interesting that another somite-dependent periodicity has been detected that involves the preganglionic sympathetic neurons in the thoracic region of the chick spinal cord (Forehand et al., 1994; 1998). Within the sympathetic trunk their axons project either $\mathrm{A}$ (rostral) or $\mathrm{P}$ (caudal) depending on their A-P position of origin in the cord, and here the parent neurons are organized into segmental units that match the external somite periodicity. Each unit displays an internal A-P polarity with respect to the direction of axon projection in the sympathetic trunk, and this can be experimentally altered by manipulation of retinoic acid levels in single thoracic somites. Whether this reveals the operation of an internal spinal cord periodicity remains to be determined.

\section{Conclusions and future prospects}

This review emphasizes that studying the chick embryo has elucidated the basic mechanisms generating segmental patterning in the nervous system. Our analysis outlined above of peripheral nerve segmentation began with an anatomical observation about nerve growth in somites. And alongside those of others (Raper and Kapfhammer, 1990; Stahl et al., 1990) it identified growth cone repulsion as an essential axon guidance mechanism.

Extending Viktor Hamburger's dictum that the embryo 'is the only teacher who is always right', we would add that this teacher can also lead us in unexpected directions. Some time ago we identified a growth cone collapse-inducing activity closely similar to the somite repellent in the grey matter of chicken (and mammalian) brain (Keynes et al., 1991). We speculate that the somite repellent system, which blockades growing peripheral axons, has been co-opted in the mature CNS, for example to regulate neural plasticity. Together with the recent identification of the somite repellent (Keynes \& Cook, unpublished observations) this will be interesting to explore in the future, and provides another example of the potential range and influence of the chick embryo.
DI BONITO M, GLOVER JC, STUDER M (2013). Hox genes and region-specific sensorimotor circuit formation in the hindbrain and spinal cord. Dev Dyn 242: 1348-1368.

FLEMINGA, KISHIDAMG, KIMMELCB, KEYNES RJ (2015). Building the backbone: the development and evolution of vertebral patterning. Development 142: 1733-1744.

FOREHAND CJ, EZERMAN EB, GOLDBLATT JP, SKIDMORE DL, GLOVER JC (1998). Segment-specific pattern of sympathetic preganglionic projections in the chicken embryo spinal cord is altered by retinoids. Proc Natl Acad Sci USA 95: 10878-10883.

FOREHAND CJ, EZERMANEB, RUBIN E, GLOVERJC (1994). Segmental patterning of rat and chicken sympathetic preganglionic neurons: correlation between soma position and axon projection pathway. $J$ Neurosci 14: 231-241.

FORTIN, G., CHAMPAGNAT, J. and LUMSDEN, A. (1994). Onset and maturation of branchio-motor activities in the chick hindbrain. Neuroreport 5: 11491152.

FRASER, S., KEYNES, R. and LUMSDEN, A. (1990). Segmentation in the chick embryo hindbrain is defined by cell lineage restrictions. Nature 344: 431-435.

GAMMILL LS, GONZALEZ C, GU C, BRONNER-FRASER M (2006). Guidance of trunk neural crest migration requires neuropilin $2 /$ semaphorin $3 \mathrm{~F}$ signaling. Development 133: 99-106.

GARCÍA-MARÍN V, GARCÍA -LOPEZ, P. \& FREIRE, M. (2009). The growth cone as seen through Cajal's original histological preparations and publications. J. Hist. Neurosci. 18: 197-210.

GIUDICELLI F, TAILLEBOURG E, CHARNAY P, GILARDI-HEBENSTREIT P (2001). Krox-20 patterns the hindbrain through both cell-autonomous and non cellautonomous mechanisms. Genes Dev 15: 567-580.

GÓMEZ-GAVIRO MV, BALABAN E, BOCANCEA D, LORRIO MT, POMPEIANO M, DESCO M, RIPOLL J, VAQUERO JJ (2017). Optimized CUBIC protocol for three-dimensional imaging of chicken embryos at single-cell resolution. Development 144: 2092-2097.

GUTHRIE S, LUMSDEN A (1991). Formation and regeneration of rhombomere boundaries in the developing chick hindbrain. Development 112: 221-229.

HAMBURGER V, HAMILTON HL (1951). A series of normal stages in the development of the chick embryo. J Morphol 88: 49-92.

HARRIS H (2000). The Birth of the Cell. Yale: Yale University Press.

HILL C (1899). Primary segments of the vertebrate head. Anatomischer Anzeiger 16: 353-369.

HUBER AB, KANIA A, TRAN TS, GU C, DE MARCO GARCIA N, LIEBERAM I, JOHNSON D, JESSELL TM, GINTY DD, KOLODKIN AL (2005). Distinct roles for secreted semaphorin signaling in spinal motor axon guidance. Neuron 48: 949-964. 
HUGHES DS, KEYNES RJ, TANNAHILL D (2009). Extensive molecular differences between anterior- and posterior-half-sclerotomes underlie somite polarity and spinal nerve segmentation. BMC Dev Biol 9: 30

ITASAKI N, BEL-VIALAR S, KRUMLAUF R (1999). Shocking' developments in chick embryology: electroporation and in ovo gene expression. Nat Cell Biol 1: E203-7.

JACQUIN TD, BORDAY V, SCHNEIDER-MAUNOURY S, TOPILKO P, GHILINI G, KATO F, CHARNAY P, CHAMPAGNAT J (1996). Reorganization of pontine rhythmogenic neuronal networks in Krox-20 knockout mice. Neuron 17: 747-758.

KAPFHAMMER JP, RAPER JA (1987). Collapse of growth cone structure on contact with specific neurites in culture. J Neurosci 7: 201-212.

KEYNES R, TANNAHILL D, MORGENSTERN DA, JOHNSON AR, COOK GM, PINI A (1997). Surround repulsion of spinal sensory axons in higher vertebrate embryos. Neuron 18: 889-897.

KEYNES RJ, JOHNSON AR, PICART CJ, DUNIN-BORKOWSKI OM, COOK GM (1991). A growth cone collapsing activity in chicken gray matter. Ann N Y Acad Sci 633: 562

KEYNES RJ, STERN CD (1984). Segmentation in the vertebrate nervous system. Nature 310: 786-789.

KEYNES RJ, STERN CD (1988). Mechanisms of vertebrate segmentation. Development 103: 413-429.

KOHL A, HADAS Y, KLAR A, SELA-DONENFELD D (2012). Axonal patterns and targets of dA1 interneurons in the chick hindbrain. J Neurosci 32: 5757-5771.

KÖNTGES G, LUMSDEN A (1996). Rhombencephalic neural crest segmentation is preserved throughout craniofacial ontogeny. Development 122: 3229-3242.

KRUMLAUF R (2016). Hox Genes and the Hindbrain: A Study in Segments. Curr Top Dev Biol 116: 581-596.

KULESA PM, BAILEY CM, COOPER C, FRASER SE (2010). in ovo live imaging of avian embryos. Cold Spring Harb Protoc 2010: pdb.prot5446.

KULESA PM, FRASER SE (2000). In ovo time-lapse analysis of chick hindbrain neural crest cell migration shows cell interactions during migration to the branchial arches. Development 127: 1161-1172.

LANCE-JONES C, LANDMESSER L (1980). Motoneurone projection patterns in the chick hind limb following early partial reversals of the spinal cord. $J$ Physiol 302: 581-602.

LEWIS J (1984). On to the vertebrates. Nature 310: 724-725.

LIENERIE, SHARONN, GOLDSTEIN IJ (1986). The Lectins. Academic Press, Orlando.

LUMSDEN A, KEYNES R (1989). Segmental patterns of neuronal development in the chick hindbrain. Nature $337: 424-428$.

MELLITZER G, XU Q, WILKINSON DG (1999). Eph receptors and ephrins restrict cell intermingling and communication. Nature 400: 77-81.

MOMOSE T, TONEGAWA A, TAKEUCHI J, OGAWA H, UMESONO K, YASUDA K (1999). Efficient targeting of gene expression in chick embryos by microelectroporation. Dev Growth Differ 41: 335-344.

MURAMATSU T, NAKAMURA A, PARK HM (1998). In vivo electroporation: a powerful and convenient means of nonviral gene transfer to tissues of living animals (Review). Int J Mol Med 1: 55-62.

MURPHY P, DAVIDSON DR, HILL RE (1989). Segment-specific expression of a homoeobox-containing gene in the mouse hindbrain. Nature 341: 156-159.

NEAL HV (1918). Neuromeres and metameres. J. Morphol. 31: 293-315.

OISHI I, YOSHII K, MIYAHARA D, KAGAMI H, TAGAMI T (2016). Targeted mutagenesis in chicken using CRISPR/Cas9 system. Sci Rep 6: 23980.

ORR H (1887). Contribution to the embryology of the lizard. J. Morphol. 1: 311-372.
PARKERHJ, BRONNER ME, KRUMLAUF R (2014). A Hox regulatory network of hind brain segmentation is conserved to the base of vertebrates. Nature 514: 490-493.

PERETZ Y, EREN N, KOHL A, HEN G, YANIV K, WEISINGER K, CINNAMON Y, SELA-DONENFELD D (2016). A new role of hindbrain boundaries as pools of neural stem/progenitor cells regulated by Sox2. BMC Biol 14: 57.

PRIN F, SERPENTE P, ITASAKI N, GOULD AP (2014). Hox proteins drive cell segregation and non-autonomous apical remodelling during hindbrain segmentation. Development 141: 1492-1502

RAPER JA, KAPFHAMMER JP (1990). The enrichment of a neuronal growth cone collapsing activity from embryonic chick brain. Neuron 4: 21-29.

REMAK R (1841). Uber die Entstehung der blutkorperchen. Medicinische Zeitung 10: 127.

REMAK R (1855). Untersuchungen über die Entwicklung der Wirbelthiere. Reimer, Berlin.

RICKMANN M, FAWCETT JW, KEYNES RJ (1985). The migration of neural crest cells and the growth of motor axons through the rostral half of the chick somite. $J$ Embryol Exp Morphol 90: 437-455

SAGA Y (2012). The mechanism of somite formation in mice. Curr Opin Genet Dev 22: $331-338$

SAGA Y, HATA N, KOSEKI H, TAKETO MM (1997). Mesp2: a novel mouse gene expressed in the presegmented mesoderm and essential for segmentation initiation. Genes Dev 11: 1827-1839.

STAHL B, MÜLLER B, VON BOXBERG Y, COX EC, BONHOEFFER F (1990). Biochemical characterization of a putative axonal guidance molecule of the chick visual system. Neuron 5: 735-743.

STEKETEE MB, TOSNEY KW (1999). Contact with isolated sclerotome cells steers sensory growth cones by altering distinct elements of extension. J Neurosci 19 : 3495-3506.

STERN CD, JAQUES KF, LIM TM, FRASER SE, KEYNES RJ (1991). Segmental lineage restrictions in the chick embryo spinal cord depend on the adjacent somites. Development 113: 239-244.

STERN CD, SISODIYA SM, KEYNES RJ (1986). Interactions between neurites and somite cells: inhibition and stimulation of nerve growth in the chick embryo. $J$ Embryol Exp Morphol 91: 209-226.

STREETER GL (1933). The status of metamerism in the central nervous system. J. Comp. Neurol. 57: 455-475.

SUN J.J., KEY, M., MARTINEZ, V.K., MORALES, F.S., ZHU P., RAY, R.S. (2017). Embryonic rhombomere hindbrain patterning delineates distinct functional neuron populations in the adult central noradrenergic system. FASEB J. 31: Supplement 1053.8.

VÉRON N, QU Z, KIPEN PA, HIRST CE, MARCELLE C (2015). CRISPR mediated somatic cell genome engineering in the chicken. Dev Biol 407: 68-74.

VON BAER KE (1828). Über die Entwicklungsgeschichte der Thiere. Königsberg.

WANG L, YANG L, GUO Y, DU W, YIN Y, ZHANG T, LU H (2017). Enhancing targeted genomic DNA editing in chicken cells using the CRISPR/Cas9 system. PLoS One 12: e0169768.

WILKINSON DG, BHATTS, CHAVRIER P, BRAVO R, CHARNAYP (1989). Segmentspecific expression of a zinc-finger gene in the developing nervous system of the mouse. Nature 337: 461-464.

XU Q, MELLITZER G, ROBINSON V, WILKINSON DG (1999). In vivo cell sorting in complementary segmental domains mediated by Eph receptors and ephrins. Nature 399: 267-271.

ZHAO W, AJIMA R, NINOMIYA Y, SAGA Y (2015). Segmental border is defined by Ripply2-mediated Tbx6 repression independent of Mesp2. Dev Biol400: 105-117. 


\section{Further Related Reading, published previously in the Int. J. Dev. Biol.}

Segment formation in Annelids: patterns, processes and evolution

Guillaume Balavoine

Int. J. Dev. Biol. (2014) 58: 469-483

https://doi.org/10.1387/ijdb.140148gb

Molecular mechanisms controlling brain development: an overview of neuroepithelial secondary organizers Claudia Vieira, Ana Pombero, Raquel García-Lopez, Lourdes Gimeno, Diego Echevarria and Salvador Martínez

Int. J. Dev. Biol. (2010) 54: 7-20

https://doi.org/10.1387/ijdb.092853cv

Segmentation, metamerism and the Cambrian explosion

Juan Pablo Couso

Int. J. Dev. Biol. (2009) 53: 1305-1316

https://doi.org/10.1387/ijdb.072425jc

Hindbrain signals in otic regionalization: walk on the wild side

Sylvie Schneider-Maunoury and Cristina Pujades

Int. J. Dev. Biol. (2007) 51: 495-506

https://doi.org/10.1387/ijdb.072345ss

The isthmic organizer and brain regionalization

S Martínez

Int. J. Dev. Biol. (2001) 45: 367-371

http://www.intjdevbiol.com/web/paper/11291867

Orienting axon growth: spinal nerve segmentation and surround-repulsion

D Tannahill, J M Britto, M M Vermeren, K Ohta, G M Cook and R J Keynes

Int. J. Dev. Biol. (2000) 44: 119-127

http://www.intjdevbiol.com/web/paper/10761856

Segmentation of the vertebrate hindbrain: a time-lapse analysis

P M Kulesa and S E Fraser

Int. J. Dev. Biol. (1998) 42: 385-392

http://www.intjdevbiol.com/web/paper/9654023

5 yr ISI Impact Factor $(2016)=2.421$
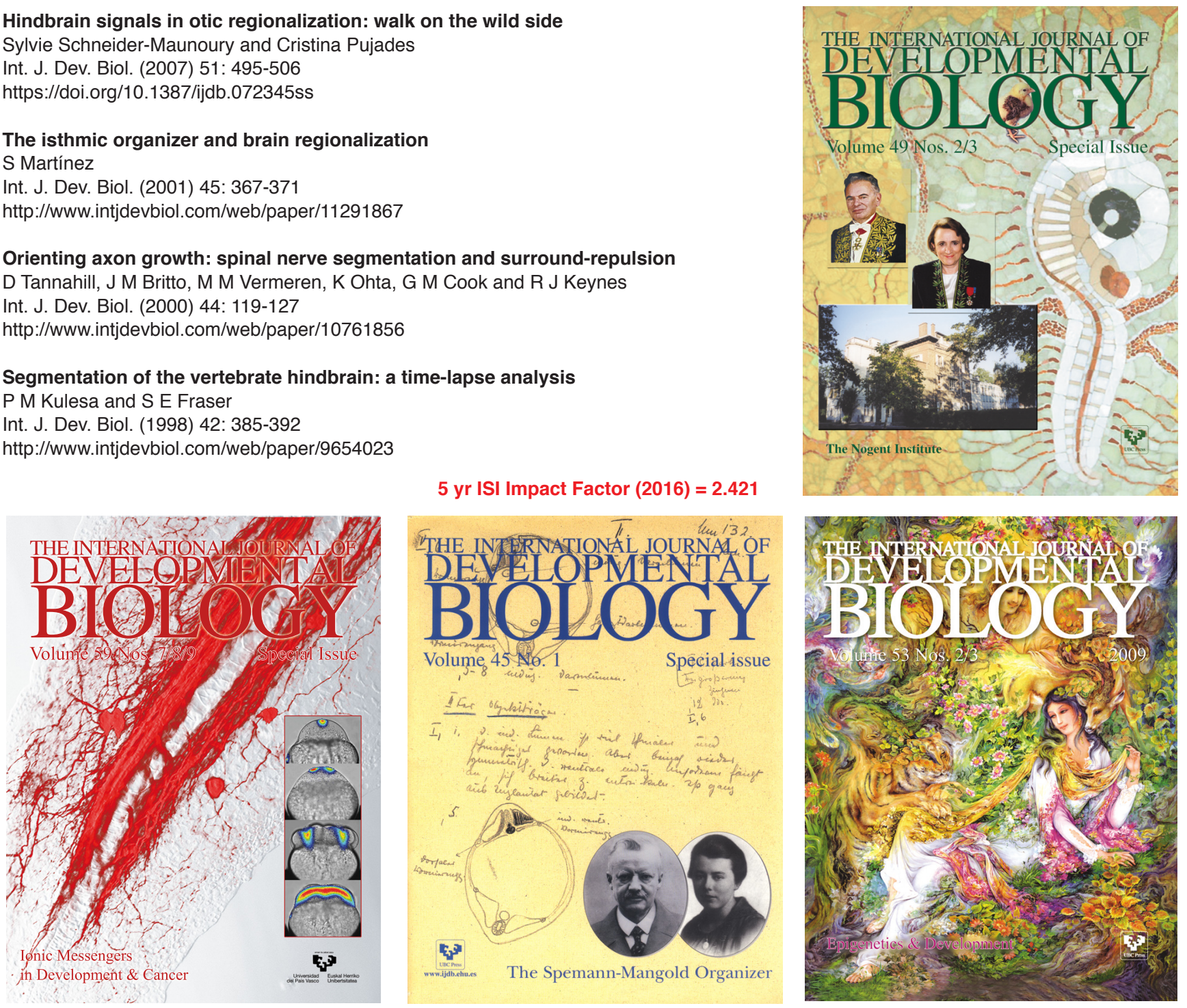